\title{
Stories of Telltale Eyes
}

\author{
Filmic Gaze and Spectatorial Agency \\ in Krzysztof Kieślowski's A Short Film about Love, \\ Ferzan Ozpetek's Facing Windows, \\ and Wes Anderson's Moonrise Kingdom
}

\section{BORBÁLA LÁSZLÓ}

Abstract: This paper attempts to rethink the concept of the filmic gaze through a comparative analysis of three films, namely, Krzysztof Kieślowski's Krótki film o miłości (A Short Film about Love, 1988), Ferzan Ozpetek's La Finestra di Fronte (Facing Windows, 2003), and Wes Anderson's Moonrise Kingdom (2012). 'Filmic gaze' here refers not to the production of the filmic/ discursive self through suture but to the whole fabric of the film, which is construed as a looking subject. Kaja Silverman's cinematic suture theory and Descartes's dark room parable are employed to illustrate how the passivising filmic gaze of classical narrative cinema confines the spectator to the position of the voyeur, who observes rather than creates the scene that pleases her. A Short Film about Love $i$ analysed to demonstrate conventional film-audience dynamics and is then compared with two contemporary auteur films, Facing Windows and Moonrise Kingdom, which, by addressing viewers through the characters' telltale eyes, keep reconceiving suture as they go along, blurring the boundary between intra-diegetic and extra-diegetic looks, and thus offering spectators a more active and varied spectatorial agency than that of the voyeur.

Since the 1970s, much has been said about how we are sutured into the fictional world of cinema. Most prominently, Kaja Silverman's cinematic suture theory has helped reveal the strategies through which movies address viewers and bring about certain types of spectatorial agency (47). According to Silverman's summary of the evolution of suture theory, Emile Benveniste was the first to use the term suture when referring to the subject entering a discourse, and thus splitting the self 


\section{BORBÁLA LÁSZLÓ}

into two. In Benveniste's terms, suture is the seam tying the two selves together so that the split cannot be recognised. Applying this theory to film-audience dynamics, Silverman explores how spectators lose their real subjectivity, gaining an illusionary one, the most intrinsic type of spectatorial agency, as they enter the cinematic world. "Interlocking shots," for example the "shot/reverse shot formation," ensure that spectators do not recognise the split because a convincing point of view is provided throughout the film to identify with (201). According to JeanPierre Oudart, "[e]very filmic field is echoed by an absent field, the place of a character who is put there by the viewer's imaginary, and which we shall call the Absent One" (36). In other words, the camera as well as other devices like editing, cutting, exclusion, and negation are defined as the absent "speaking subject" which conceal themselves to create "cinematic coherence and plenitude" (Silverman 205) while in fact they "speak," direct, and control the gaze of the viewing subject. In short, conventional film-audience dynamics not only facilitate but also control the viewing subject as "the spectator is identified with the gaze" created by the filmic discourse (Hayward 157).

Many films call attention to the discursive production of the viewing subject. These films, often labelled as postmodern and self-reflective, require a spectator who likes to question the pleasures provided by the classical filmic gaze, having a keen eye for artifice and all those devices that offer moments of disenchantment instead of absorption into fiction. The suture at work in such films is unique only to the degree that it grants access into the diegetic world of a self-investigating and sceptical viewing subject: the diegesis is designed to accommodate such agency and grant her the pleasure of the doubt.

The present paper will not discuss films of this kind. Instead, it focuses on films that, while producing the viewing subject in a way similar to classical cinema, also reveal their function as speaking, or in my reading, looking subjects, and in this way, they bring about a certain dynamic between film and audience which can be perceived as a form of intersubjective communication, an act of looking as distinct from watching. Thus, throughout this article, filmic gaze refers not to the creation of the filmic/discursive self through suture but to the mode of address, the whole fabric of the film, which is construed as a looking subject.

The present conceptualisation of the filmic or cinematic gaze, therefore, denounces the assumptions made by early psychoanalytic film theorists, namely Jean-Louis Baudry, Christian Metz, and Laura Mulvey, who adopted the concept 
of the Lacanian gaze into film theory as the subject's source of mastery - albeit illusory - over what he sees. Todd McGowan points out that when they introduced the notion of the filmic gaze in the 1970 s, these "traditional Lacanian film theorists" relied exclusively on Lacan's essay on the mirror-stage, thereby consolidating the idea that the spectator derives the illusion of mastery relative to what unfolds in front of his eyes (The Real Gaze 2). As Metz puts it, "the spectator is absent from the screen as perceived," but also "present there and even 'all present' as perceiver" (54). Metz contends that the spectator's agency is created by the illusion that the subject looks at the object (the film), while he is not looked at in return, which prescribes that the viewer believes to be controlling the cinematic image. Baudry explicitly links this kind of spectatorial experience to that of the mirror stage. He states that "the arrangement of the different elements - projector, darkened hall, screen - in addition to reproducing in a striking way the mis-en-scéne of Plato's cave ... reconstructs the situation necessary to the release of the "mirror stage' discovered by Lacan" (539). Furthermore, Mulvey's seminal essay "Visual Pleasure and Narrative Cinema" perpetuates the notion that the filmic gaze is associated with male spectatorship and the ideological machinations of patriarchal society.

By taking these theoretical positions into account, McGowan highlights that early psychoanalytic film theory conceives of the filmic gaze as fulfilling the function of the Imaginary - manifested in the mirror phase - and the function of the Symbolic - perpetuating ideology — while it oversees a crucial aspect of Lacanian thought regarding the Gaze, namely that of the Real (The Real Gaze 4). In Lacan's own terms, the Gaze is something that introduces "the depth of field, with all its ambiguity and variability, which is in no way mastered by me. It is rather it that grasps me, solicits me at every moment, and makes of the landscape something other than a landscape" (96). One can thus conclude that what Lacan originally means by the gaze in Seminar XI is exactly the opposite of being a source of mastery for the subject. The gaze in fact characterises the point from which the object (film) is imagined to be staring back at the subject (spectator) (Lacan 84), and for this reason, the cinematic experience is "the site of a traumatic encounter with the Real, with the utter failure of the spectator's seemingly safe distance and assumed mastery" (McGowan, "Looking for the Gaze" 29). This explains why Oudart's and Silverman's theories prove fruitful for my interpretation of the filmic gaze as coming from the film itself. While Baudry, Metz, and Mulvey stress the (mis)conception of the Lacanian Gaze as associated with mastery, suture theory reveals that 


\section{BORBÁLA LÁSZLÓ}

the gaze is projected not by the viewing subject but by the cinematic image, which controls the onlooker rather than being controlled by her.

This article argues that this notion of the filmic gaze is best explored by analysing the role of characters' acts of looking, their gestures, body language, and positioning, as well as that of optical devices representing human eyes (i.e. cameras, telescopes, binoculars), since these elements activate moments of de-suturing, coupled with the experience of our non-diegetic (real) selves being confronted. I also contend that stories centred around the motif of looking (peeping, voyeurism, scopophilia) are the most useful to explore the nature and types of the filmic gaze.

My argument is that the majority of films do not create eye contact with, do not look at but through the spectator, who is immersed into the diegetic universe, treated as a passive observer, a voyeur. This role, however, is not completely identical with that of the voyeur as it is understood in psychoanalysis, because the scene she derives pleasure from is not created by the spectator but by the film, which in this sense is a much more active looking agent than the viewer. As I will argue, films which look through spectators and treat them as voyeurs project a passivising filmic gaze, while those which look at spectators perform an act of looking that gives viewers a more active spectatorial agency.

Drawing upon theories of the cinematic suture, film scholars have realised that the notion of the filmic gaze as it was reconceptualised by the criticism of early psychoanalytic film theory is worth looking at academically. In the following paragraphs I shall highlight Tom Gunning's and Timothy Corrigan's theories of film reception, since both are based on the hypothesis that the mode of address determines the whole fabric of the film.

In this regard, Gunning's genealogy demarcates early-modern, pre-1906 cinema, which he terms the "cinema of attractions" and post-1906, dominant, "narrative cinema" (Gunning's genealogy described in Staiger 13). While the "cinema of attractions" addressed the audience directly so as to confront, astonish, emotionally and critically engage spectators - which effects were mostly achieved through the actors' "mischievous contact with the camera" (Brown 4) - the "cinema of narrative integration" absorbed viewers into fiction, treating them as "static, passive observers" (Staiger 13). According to Gunning, the distinction between the opposing types of cinematic address evolved as follows: 


\section{STORIES OF TELLTALE EYES}

The performers in the cinema of attractions greeted the camera's gaze with gusto, employing glances, winks and nods. With the establishment of a coherent diegesis, any acknowledgment of the camera became taboo, condemned by critics as destructive of the psychological effect essential for an involved spectator. (Origins of American Narrative Film 261)

As the use of direct address has been resumed in postmodernist and contemporary cinema, Gunning, who initially connected the technique to modernist filmmaking, also admitted that "[t]he cinema of attractions persists in later cinema ... provid[ing] an underground current floating beneath narrative logic and diegetic realism ("An Aesthetic of Astonishment" 826). Thus, one of the strengths of Gunning's theory is that it does not conceptualise the filmic gaze as something completely circumscribed by dominant cultural practices. This is important because, as I argue, it is not only postmodernist, highly self-reflexive films that can engage viewers in the meaning-making process, and, by the same token, it is not only classical narrative cinema that can confine viewers to the role of passive observers. It is crucial to see that films can address, or, in my interpretation, look at or through spectators irrespective of paradigmatic categorisations.

Gunning's genealogy also takes the fact into account that the gaze of the whole cinematic text is largely determined by the actors' stance vis-a-vis the camera. Indeed, the filmic gaze is often expressed through the characters' extra-diegetic glances. Breaking through the fourth wall, however, is not the sole condition of looking at the audience, and Gunning's theory fails to recognise this: it only mentions two modes of address, suggesting that films treat us either as passive voyeurs or as active looking subjects. Thus, the question is: what about the movies that seem to establish a coherent diegesis only to begin ogling us? Or what about those in which direct address is integrated into the diegetic universe? Such films fit neither the category of "narrative cinema" nor that of the "cinema of attractions."

Using a similar binary categorisation, Corrigan distinguishes between "gaze" and "glance cinema" (62). He contends that with the increasing significance of televisual media in the $1980 \mathrm{~s}$, audiences watched movies "according to a glance aesthetic rather than a gaze aesthetic" (62), by which he means that films were "watched across distractions rather than the collective gaze" of spectators, and as such, they 


\section{BORBÁLA LÁSZLÓ}

disrupted mechanisms of "primary identification" through which cinema sutures viewers into the filmic text (16).1 As for the historical categorisation of the filmic gaze,

Corrigan creates the categories of "pre-classical cinema" (1895 to circa 1917), "classical and modernist cinema" (1917 to the present and 1950 to the present, respectively), and "postmodern cinema" (1970s to the present). Like the other theorists, Corrigan creates his system focusing on the experience of the spectator. Emphasising an opposition between the "glance" and the "gaze," he argues that preclassical and postmodern cinema encourages sporadic attention to the screen, while classical and modernist cinema is a gaze cinema. The gaze cinema creates a fixed subjectivity and unified identity through its narrative continuities, closures, central characters, and flexible realism. For the spectator, the gaze cinema is a cinema of interpretation and reading, while a glance cinema is one of performance. (Staiger 15)

The problem is that by glance cinema Corrigan means a type of spectatorial agency based on coherent performativity, a definite, unfailing cooperation in the meaning-making process; thus, glance cinema defines movies that steadily gaze at viewers. Once again, we are left with two types of cinema, each implying a corresponding type of the filmic gaze - one that passivises and one that activates - and the question arises: what about the look that oscillates? As this happens often enough in contemporary arthouse and auteur movies, it might be more useful to theorise the film's gaze by considering the distinction between mainstream and independent cinema.

Hollywood films prefer either a restricted or an omniscient mode of address to ensure that spectators are sutured into the illusory reality of the fictional world ("Key Aspects of Media Studies"). Although I cannot compare this scenario to a form of intersubjective communication, it cannot be perceived as the objectification of viewers either. Instead, it evokes the situation of the bearded man in Descartes's engraving from his Optics: locked in a dark room, the only view he can get of the external

1 Corrigan's distinction between "gaze" and "glance aesthetic" can be traced back to John Ellis's Visible Fictions, wherein these terms were used to distinguish between watching movies (gazing) and watching television (glancing). 
world is through the eye of a human being inserted in the wall. As Miran Bozovic explains, Descartes wanted to emphasise that we "can never step out but are forever entrapped in a room in which we deal with our retinal images only and never with things themselves" (162).

This parable can also be seen as an illustration of the gaze of Hollywood films which tend to act upon the limitations instead of the possibilities of human visual perception: we are bound to look at the film, but it does not look at us in return, since it is constructed as the external world which one sees only from the dark room of his or her own perspective. ${ }^{2}$ In other words, classical narrative cinema re-enacts the "impossibility of stepping out from the world of imitations, copies and simulacra" (Bozovic 162) so that we are not offered more than an absolute point of view, "a point of interiority which can never be externalised . . . a point at which we can be nothing but voyeurs" (164). To put it simply, mainstream cinema restricts the spectator's agency to the role of the voyeur who believes to be the subject of the gaze, hence her feeling of being deeply sutured into the diegesis. Similar to Silverman's suture theory, Descartes's parable thus helps expose the conventional dynamics between film and viewer, the dichotomy between scene and voyeur, the looking and viewing subject.

In contrast to mainstream cinema, independent films frequently suggest the possibility - however illusory - of splitting up suture and providing a more active, if more troubled, spectatorial agency. Often their aim is precisely to reveal the seam that ties us to the absolute point of view of the voyeur. Yet the films which interest me are those that combine different mechanisms, thereby creating ambiguities concerning the binary categorisation of movies based on the mode of address. Since they are characterised by a hybrid, oscillating gaze, these films belong neither to the "cinema of attractions" nor to "narrative cinema," neither to "glance" nor "gaze cinema," and they definitely do not project the passivising gaze of Hollywood films.

The movies in the focus of this article neither look through nor look consistently at viewers, they just sometimes glance at us through a character's telltale eyes to create a momentary, illusory blurring of boundaries between the act of watching and the act of looking. Unlike highly self-reflexive postmodernist movies, they do not fully deconstruct conventional dynamics between film and viewer, questioning their status as spectacle and ours as voyeur. Seemingly, their objective is an attempt to look

2 This does not mean that watching Hollywood films is an unbearable experience: we readily suspend our disbelief in exchange for the pleasures of viewing (Rowe 88). 


\section{BORBÁLA LÁSZLÓ}

"inside" at us, bearded men, who are forever locked in the dark room of our visual perception. Considering the whole fabric of these films as a looking subject, we find that their gaze does not come across as unrelenting but as tentative, squinting, and ambiguous. For certain moments and in certain ways - not exclusively through direct address - they create a contact with the audience which can be construed as the eye contact between two human subjects.

Summarising what has been said so far, I shall argue for the relevance of the notion of filmic gaze as projected by the film itself, analysing four films in terms of how I imagine they look at viewers. The motif of the gaze in its broadest sense is central in each movie, and the filmic gaze is expressed most emphatically by the main characters who meaningfully stare through windows. Silverman's suture theory and Descartes's parable are employed to show that these characters' position as voyeurs is at the same time a reference to the voyeuristic agency of viewers. However, if one construes the whole fabric of these films as a looking subject, it appears that they relate to the audience differently. To begin with, I briefly refer to Hitchcock's Rear Window (1954) to demonstrate conventional film-audience dynamics because, as I will argue, despite its use of postmodernist techniques, it only reflects on the limitations of our visual agency. To support the argument that not only Hollywood movies passivise the spectator, I also examine an auteur film from the European tradition, namely, Krzysztof Kieślowski’s Krótki film o mitości (A Short Film about Love, 1988). Although the narrative of the latter also revolves around the trope of the gaze, similarly to Rear Window, it sustains its function as mere image and ours as observer. La Finestra di Fronte (Facing Windows, 2003), directed by Ferzan Ozpetek, seems to follow the traditions of narrative cinema; however, in certain scenes and in its special ways, it calls for a self-reflexive mode of watching, treating viewers both as observers and looking subjects. Since the "eyes" of Facing Windows do not stare at us consistently, Ozpetek's drama serves as one of my examples for the oscillating filmic gaze. Among the four films, the one that illustrates most clearly the hybridity of visual address is Wes Anderson's Moonrise Kingdom (2012), yet another example of auteur cinema, which drastically oscillates between treating the viewers as passive voyeurs and as active looking subjects. 
Classical Film-Audience Dynamics:

How Do Films Look Through Spectators?

As a representative example of Hollywood cinema, Rear Window demonstrates that the use of meta-cinematic devices does not necessarily entail intersubjective communication with viewers. In my reading, Rear Window - as a looking agent - does not bring about an active spectatorial agency, because the camera consistently identifies viewers with the protagonist's point of view, thereby absorbing them into the fiction, and treating them as passive observers. The film's mode of address is solidified, and as such, it does not aim to initiate a type of communication resembling actual acts of looking. Instead, Rear Window makes references to the voyeuristic mode of watching films to reveal how restricted the dynamics between film and audience are. As such, this example shall serve perfectly to explain how spectators are sutured into the fictional world of cinema, and at the same time, to illustrate Descartes's dark room parable about the limitations of human visual experience.

If Rear Window is indeed a "metaphor for cinema" in which Jeffries stands for the audience (Mulvey 23), the whole filmic text can be read as a rendering of the spectator's inability to escape the viewpoint provided by the looking subject. The viewer's limited agency is underpinned by Jeffries's constrained physical position - being tied to a wheelchair - as a result of which his perspective is as severely restricted by his binoculars and his camera as that of the viewers by cinematic technicalities (movements, positions of the camera, and editing). Memorable references to this shared position are the scenes in which Jeffries zooms in on the flats opposite: the dark framing of the camera is a direct reference to the filming device that controls our gaze. As Silverman argues, Rear Window "foregrounds the voyeuristic dimensions of the cinematic experience, making constant references to the speaking subject" (206). Another example in this regard is the episode when Thorwald suddenly looks back at Jeffries and later comes to attack him in his apartment. The alarming sound of Thorwald's footsteps, his menacing stare, the ominous glare of his cigarette in the darkness, his silhouette coming closer and closer reminds viewers that, similarly to Jeffries, we only wish to but are unable to control the spectacle. In our relation to the cinematic image, we are as immobile and helpless as Jeffries.

In Mladen Dolar's interpretation, "Rear Window is the Hitchcockian presentation of the Panopticon, his illustrative application of Bentham and Foucault" (144), since the flats opposite Jeffries's rear window evoke the cells under the pervasive scrutiny 


\section{BORBÁLA LÁSZLÓ}

of the Supervisor's controlling gaze. Yet, while in Bentham's and Foucault's Panopticon it is the prisoners who live in constant fear of the gaze they cannot see, in Rear Window, it is Jeffries who lives in permanent fear in his watchtower, troubled by fact that he cannot make his gaze ubiquitous (as an evidence of his powerlessness, he is asleep at the time of the murder). As Dolar concludes, "the inhabitants are not the prisoners of the gaze of the Other, with its invisible omnipresence; it is rather the Supervisor who is the prisoner, the prisoner of his own gaze - a gaze that does not see" (144). By connecting the experience of Jeffries with that of the viewers, the aim of metacinematic devices in Rear Window is thus to expose the conventional framework of watching films, according to which spectators wish to pervade the cinematic image with their gaze yet can only behold it from the position of peepers, as if through binoculars and a rear window.

By the same token, Rear Window can be interpreted as a re-enactment of the limitations of human visual perception as such where the window represents eyes. According to this metaphor, the window shades rolling up in the first scene are the eyelids opening to the external world. As Bozovic claims, "[ $\mathrm{t}]$ hat the window we are looking through functions virtually as an eye is evident from the fact that the room itself functions as a camera obscura - what unfolds in the room on this side of the window is precisely the inverted image of what unfolds beyond the window of the flat on the opposite side of the courtyard - the Thorwalds' flat" (162). Jeff on this side is immobilised in a manner similar to Thorwald's wife on the opposite side, and the actions of these two characters are subordinated to those of their mobile partners, Lisa and Lars, respectively. This insight informs Bozovic's comparison of Jeff's room with the dark room in Descartes's parable: both spaces represent "the world of imitations, copies, and simulacra" in which we are all entrapped (163). In agreement with former criticism, I therefore believe that Rear Window, with its allusions to the limitations of the spectator's agency and of human visual perception, looks through rather than at viewers, or, in other words, it aims not to modify suture, but, as Zizek describes Hitchcock's works, “to pursue the transferential fiction to the end" (10).

\section{The Passivising Gaze of $A$ Short Film about Love}

Being chiefly about love, "about how lust and love look at people and how they look to them" (Reeve 271), Kieślowski's A Short Film about Love represents a specific mode 
of looking at the world, where the scope of sight is determined and distorted by desire. The trope of love makes this film a more nuanced rendering of voyeurism than Rear Window, yet, rather than providing spectators a more active agency than that of the observer, it only enhances the sense of being confined to a limited perspective.

A Short Film about Love is the feature length version of a part of Kieślowski's 1988 television series, Dekalog. It begins with a flashforward scene in which the young Tomek is dreaming about spying on his opposite neighbour, the beautiful, freespirited Magda. The narrative recounts how Tomek gradually falls in love with the older woman as he obsessively watches her performing everyday activities and entertaining men in her apartment. One day, when they meet face-to-face, Tomek admits that he has been peeping on her, and when the two eventually go on a date Tomek declares his love. Magda shatters his innocent vision by responding that there is no such thing, only sexual desire. Yet, as she tries to prove her point by seducing him, which ends in Tomek having an orgasm, feeling gravely humiliated, and trying to commit suicide, Magda develops feelings that until that point she has believed to be only a sham. In the closing scene she visits Tomek, looks through his telescope, and imagines that the boy is in her apartment, standing by her side, ready to comfort, and, presumably, love her.

The hallucinatory final scene with the main female character looking back at her former, emotionally self-contained self could imply that Kieślowski's film induces more self-reflexivity in the audience than Rear Window. This plot element, however, does not serve to address the viewers but, as I argue, merely to illustrate character development. Accordingly, the fact that the hallucinated double at the other end of the telescope does not return the gaze to establish contact with her actual self means that the film does not make eye contact with the viewers. It is also important to note that the final scene about self-reflexivity was suggested by the lead actress Grażyna Szapołowska, to satisfy “the audience's need for a conventional story" (Haltof 96), which reinforces the impression that the fabric of the film is typical of classical film-audience dynamics.

Reformulating the above hypothesis in terms of suture theory, although the film "reverses the watcher/watched roles" (Haltof 96), the audience is made to identify with the position of the voyeur even after the tables are turned within the diegesis. Initially we occupy the same field, thereby the same role as Tomek, who obsessively snoops on the sexually promiscuous life of Magda. As his obsession grows, 


\section{BORBÁLA LÁSZLÓ}

Peeping Tomek ${ }^{3}$ finds other ways to pry into Magda's life - he calls her on the phone, sends false notices to lure her into his workplace, the post office, takes a second job as a milk delivery man just to get closer to seeing her - and gradually leaves the role of the voyeur to become one of Magda's beaus. This, however, does not happen in the case of the viewers who, in their relation to the narrative, remain trapped in the space of observation until the end. In the scene when Tomek confesses his crime to Magda, the two figures standing on the street are shown from the viewpoint of a spy hiding behind a car, which implies that even if the camera dissolves a subjective point of view, it does so only to switch to another subjective or an omniscient perspective. After Tomek is sexually humiliated, as a result of which he tries to slash his wrists, the audience remains with Magda, who starts obsessively monitoring Tomek's apartment through a pair of opera glasses. Therefore, while "the object of voyeurism becomes the voyeur" and "the loved one becomes the lover" in the diegetic world (Berardinelli), neither the film nor the spectator changes their roles - the former remains scene, the latter remains observer.

Let us not forget, however, that the movie suggests the possibility - even if only within the diegesis - of creating intersubjectivity, empathy, and understanding through looking. Most importantly, this appears in the form of character developments which are analogous with Tomek and Magda's changing attitude towards love. Tomek's yearning to see Magda, which is initially not different from the physiological cravings of hunger, thirst, and sleep, gradually grows into a kind of love which urges him to initiate actual, not exclusively one-way communication with the desired woman. Thus, when Magda asks Tomek whether he masturbated while looking at her, the boy's answer is: "I used to, but not anymore." The scene when the two go on an actual date also signals the gradual transformation of Tomek's voyeuristic desires into a less objectifying affection.

The female protagonist goes through an even more radical development. After his suicide attempt, she desperately tries to call on him only to be sent away by the over-protective landlady. Her behaviour cannot be simply explained with her bad conscience: just as Tomek develops a genuine interest in Magda, so does she in the initially repulsive boy. In fact, they so thoroughly swap roles that Magda believes she can now understand Tomek's psychological motivations and can

3 The name I use here is a pun which comes about by piecing together the character's name and the commonly known nickname, peeping Tom, referring to the male voyeur. 
completely identify with his point of view. As Reeve remarks, "even the musical leitmotif that was his signature at the beginning of the film becomes hers" (282).

The illusion of identifying with the other's perspective is condensed in the final scene in which Magda peeps through Tomek's telescope and hallucinates that she is watching her own self, who apparently finds comfort, reconciliation, and love in the person of Tomek. If one disregarded the fact that with this happy ending the filmmakers wanted to achieve the effects of a conventional love story, the final scene could be perceived as a metacinematic gesture. Yet, the tables are not turned in terms of the film-audience dichotomy, exactly because the aim to please the viewers is that of the passivising filmic gaze, which also explains why looking is represented as inescapably delusive in the movie. ${ }^{4}$

A Short Film about Love can be seen as the intertext of Rear Window, inasmuch as it also uses the motif of windows as a metaphor for human eyes. Still, whereas the rectangular rear window in Hitchcock's film stands for the limitations of human visual perception in general, the circular glass surfaces in Kieślowski's film epitomise vision which is inescapably distorted by desire. The lens of Tomek's telescope, the convex lens hanging on the window pane in Magda's living room, the snowball she gets as a present, the round hole in the wall of Tomek's post office cubicle, to mention only a few of several similar objects appearing in the film, signify the deformity and the circular pattern of perception that any person in love would be unable to break.

In this sense, one cannot talk about character development either, since, as Danusia Stok explains, Magda and Tomek "are going round and round in circles, ... not achieving what they want" (145), namely, a clear vision of the other that could be the basis of their mutual, intimate love. Although the film's ending suggests that "when done with love [looking] can lead to seeing and understanding" (Reeve 285), the overwhelming presence of circular motifs undermines this message, and shows how vision can "feed the obsessive circle of fantasy" (285). Knowing that the positive ending of $A$ Short Film about Love was created with the intention of pleasing the audience further problematises the optimistic representation of vision. To sum up, although Kieślowski's drama is a beautifully implemented, visually sophisticated depiction of looking when in love, it reinforces limited spectatorial agency by reenacting the impossibility of the viewer's escape from the position of the voyeur.

4 The opening scene that shows Tomek dreaming about peeping on Magda is a flash-forward to the final hallucinatory scene, which renders the rest of the movie effectively a flashback, a double delusion, Tomek's dream distorting ab initio the view of the whole representational world. 


\section{BORBÁLA LÁSZLÓ}

Therefore, similarly to Rear Window, A Short Film about Love consistently looks through rather than at spectators.

\section{The Telltale Eyes of Facisg Windows}

Ferzan Ozpetek's Facing Windows, an example of contemporary auteur cinema, looks at viewers differently. In my reading, it destabilises the conventional dynamics between spectacle and spectator, because it occasionally urges viewers to reflect on their limited voyeuristic agency. This is achieved by three distinct but interrelated means: 1) by refusing the objectifying influence of voyeurism within the diegesis; 2) by providing a multiplicity of perspectives to be identified with; and 3) by creating thorough ambiguity concerning the distinction between fiction and reality, which culminates in a crucial hallucinatory scene. It must be noted, however, that not even in this emotionally elevated, illusory moment does the main character look directly outwards, and, in this sense, Facing Windows too is an example of classical narrative cinema. Yet, I argue that the filmic gaze addresses the audience mainly through the main character Giovanna's telltale eyes, as she is able to establish a confidential relationship with the viewers through the camera.

Indeed, the story is told through and by Giovanna's eyes, from which it follows that Facing Windows displays specific features of the "cinema of attractions." The main character's positioning (more precisely, doubling) and the undefinable direction of her gaze make the spectator self-conscious, the movie ambiguously metafictional, and the gaze of the whole filmic text oscillatory, meaning that it occasionally and implicitly blurs the boundary between the act of watching and actual looking. By inciting spectators to detach themselves from the point of view of the voyeur, that is, the perspective they had originally adopted, Facing Windows requires self-reflection from viewers, offering a more active spectatorial agency than either Rear Window or A Short Film about Love. This also implies that identification here is different from that in the other two movies and is rather conceived "as a series of shifting positions [which] assumes that cinematic identification is as fragile and unstable as identity itself" (Mayne 27). In short, the movie's oscillating gaze results in an inconsistent spectatorial agency.

In Facing Windows, the viewers see mainly through the eyes of Giovanna, a young mother of two children, an always nagging wife. Her disgruntlement is not unrelated to her unfulfilled desire to become a pastry chef; she works as an accountant 
in a poultry factory. Her yearning is, as it were, sublimated into the habit of peeping: she secretly gazes at the window of the opposite apartment and its handsome resident, Lorenzo. The two eventually meet, and they together end up looking after an old man who is walking the streets of Rome unconsciously, suffering from partial memory loss. While helping Davide unfold his story and regain his identity, Lorenzo and Giovanna's romantic interest in each other also develops toward its climax.

Although it is about love, Facing Windows refuses the objectifying, passivising influence of voyeurism. Early in the film, Giovanna's daughter says: "I told you I don't feel like watching TV," and she would prefer to help the adults arrange groceries. At this point, it seems that Martina inherited the willfulness of her mother, who is similarly obsessed with order, annoyed by any disruption or intrusion into her vision. ${ }^{5}$ Giovanna's stubborn insistence that only her view is correct could also explain why she starts spying on Lorenzo's life, but her looks, similarly to those of Tomek in A Short Film about Love, are infused with shame: her eyes are cast down after catching something private and she always closes the window after peeping. Her behaviour betrays that she does not derive pleasure from voyeurism, and that, by watching somebody else's life, she only wants to elude the disappointments and frustrations of her own. This assumption is also supported by the fact that once she faces her disappointed self, she renounces peeping. In this sense, Martina foreshadows her mother's superiority which results from her self-reflexivity rather than from seeing more accurately than others, and in a similar manner, Giovanna focalises the spectator's self-reflexive agency when facing herself in the window in the hallucinatory scene.

Facing Windows differs from Rear Window and resembles A Short Film about Love for another reason as well: it does not confine itself to the subjective point of view of the main character. However, contrary to A Short Film about Love, where both available viewpoints are influenced by distorted vision, in Facing Windows, we are presented with a multiplicity of perspectives not all of which are infused with the delusions of voyeuristic desire. The first scene that disperses the main female character's dominant point of view is the one in which we learn that Giovanna and Lorenzo engage in mutual voyeurism: Giovanna's friend Eminé reveals to her that "He spied on you just like you spied on him." In this light, Lorenzo's perspective is added to that of Giovanna, even if only as its duplication. When, however, Davide appears, his

5 In a scene when Giovanna wants to report an illegal worker at the factory, her friend mockingly calls her an SS officer just to make light of her behaviour. 


\section{BORBÁLA LÁSZLÓ}

own oblique and confused perspective is also added to the others'. Therefore, gaze here is not a privilege and, at the same time, limitation, of a male hero, let alone one single character, but belongs to multiple characters and their perspectives. There are a few scenes that I shall highlight in this regard.

In what I term the "scene of the travelling gaze," Lorenzo's perspective gains narrative significance as his attention focuses on the lost Davide sitting on a fountain behind Giovanna. This implies that he is not only interested in the love affair but also dedicated to the common cause of helping the Holocaust survivor find his bearings in the present. At the same time, he passes the gaze on to Giovanna, so it can be suggested that the viewer identifies with the two characters' shared perspective, which, in addition, points beyond their desire towards each other, creating a supplement embodied in the concern for Davide.

The film also stages several instances of a phenomenon which I refer to as "the spinning gaze." In these scenes all main points of view are included and equalised in a full circle tracking shot (with montage), with the camera revolving around the characters and the perspective changing according to who holds the gaze. A crucial scene in this regard is when Giovanna, Lorenzo, and Davide are waiting for their drinks at a street bar, taking a break after the former two followed the old man's ramblings through Rome. Since a fourth male character appears on the scene, who we assume to be Davide's long-gone lover, it is here that we get the first hints of his homosexuality and of his traumatic past inflecting and confusing his present vision. These are important details from two aspects. Firstly, as Davide introduced himself from the beginning as Simone - the name of the object of his desire - his subplot mirrors the relationship of Giovanna and Lorenzo where the roles of the loved one and that of the lover are exchanged, just as in A Short Film about Love. Secondly, the presence of the past is also important here, as, by intruding into the present, it blurs temporality. Since the character sees his dead loved ones as clearly as the living around him, scenes such as this imply that according to the film's conception of memory, one never entirely loses others but retains little smithereens of them in oneself. Aided by sensory memory, the fragments of lost people make one see, hear, and smell them as if they were still here. The concept of memory as a form of intersubjectivity can also be aligned with the gaze of the film per se insofar as the latter also alludes to viewers as participants in a form of intersubjective communication. ${ }^{6}$

6 In fact, one can imagine Giovanna ambiguously addressing the audience in the same way as Davide addresses his old love, Simone. 
The role of memory is also crucial in the third scene which demonstrates the multiplicity of perspectives. This is the "scene of the dancing gaze," a music-triggered memory sequence showing Davide looking back at his past lover while dancing with Giovanna in the present. Apart from projecting on each other past and present, the scene is also significant because the act of dancing with a pretty woman, with obvious erotic overtones, gains a new, homoerotic perspective. In this way, it is not only the desirer who changes positions in Facing Windows: the object of the desire is also rendered multifarious. Scenes like those of "the travelling gaze," "the spinning gaze," and "the dancing gaze," therefore, tend to blur the dichotomy between the object and the holder of the gaze in more than one respect.

In Facing Windows, all perspectives have their own focus. What is more, these foci are also looking agents, which changes the traditional one-way relation between the holder and the object of the gaze. Metaphorically, Giovanna's gaze as a ray intersects with that of Lorenzo and, in their relationship, Davide serves as an intersection that allows the other two to connect with each other. In addition, the old man also connects past and present perspectives by unwittingly projecting past images on the present scenarios. This multiplicity and intersection of different points of view enables Giovanna to reflect on her own position, outside the circuit of the narcissistic gaze, while the spectator is also caught in a moment of reflection.

In the scene when Giovanna and Lorenzo are finally together in the latter's apartment, Giovanna goes to his window to spy on her own life - her husband, her children, her friend, and eventually the reflection of her own discontented self - and decides to leave Lorenzo for her family and to give herself the opportunity to change her carrier and start baking professionally. This cinematic moment, which "diverges from the traditional cinematic perspective that champions the male gaze, and ... assumes male spectatorship" (Occhipinti 532), also challenges cinema's role of providing pleasure for the viewer, because it reveals that the point of view we have been identifying with was affected by Giovanna's delusions. As a symbolic gesture, she takes off Lorenzo's glasses and finally sees her lifeworld as Lorenzo's fantasy in which her own self is absent and her family members are reduced to silhouettes. Unlike in A Short Film about Love, where neither Tomek nor Magda break out from the confines of voyeuristic vision, Giovanna's development implies a process of gaining clarity of vision, of coming to terms with her own repressed desires. This is why it is so important that her two selves are facing each other. The contact between her still deluded and more experienced self prevents her from satiating her voyeuristic 


\section{BORBÁLA LÁSZLÓ}

drives, helps reveal her true dream that was formerly substituted with an erotic fantasy and, in a broader sense, it also reinstates the potential of the gaze to create empathy, understanding, and intersubjectivity. Thirdly, and most importantly, even though Giovanna does not address us directly, she is positioned in a way that directs the filmic gaze at us, thus turning the whole fabric of the narrative into telltale eyes.

Although, as I have mentioned above, there is no instance of direct address in ninety-nine percent of the film, Giovanna as half-actress and half-character, a half-fictitious and half-real-life narrator plays a crucial role in conveying this story. ${ }^{7}$ As such, she could occupy a "superior epistemic position within the fictional world," which is usually allotted to characters who perform direct address in movies, and who consequently seem "to know more - or are in a position of greater knowledge within the fiction - than other characters" (Brown 14). However, since she does not acknowledge the spectator's presence but only seems to be more sensitive to it, her position cannot arise from a heightened sense of knowledge but rather from heightened sensibility - as in sensory perception - which manifests itself in her genuine flair for non-verbal communication - her voice, gaze, gestures, facial expressions, and body language - to impress others and convey meaning. Since these abilities make the character Giovanna occupy a position which one might call superior sensorial, her eyes can be perceived as projecting the filmic gaze per se.

Giovanna's superior sensorial position is epitomised by the closing scene in which we see her walking in a park and hear her voice-over: it is almost clear that she is reading out or reciting a letter written to Davide, explaining how difficult it is to forget him and all the things he had taught her. She says that when she is working in the pastry shop, she still feels the elderly man's guiding presence by her side, which recalls the definition of memory as intersubjectivity, and at the same time alludes to the assumption that the relationship between film and audience can also be regarded as intersubjective. As if to enact this concept, the closing shot features an extreme close-up on Giovanna looking directly into the camera; her eyes are smiling as if knowing something: telltale eyes.

7 An interesting fact that underpins the idea of the film initiating a form of intersubjective communication with viewers is that the characters of Giovanna and her husband Filippo are played by actors with the same names. This detail, along with the actress Giovanna's natural demeanour in relation to the camera, creates the sense of watching real people, real lives, or of hearing a first-hand account of a personal story. 
In this light, one could claim that the story is told through Giovanna's eyes. Yet, it remains difficult to decide whom Giovanna's voice and gaze are addressed at: Davide or the viewers outside the diegetic world. ${ }^{8}$ It is, however, exactly this ambiguity of address, entailing both the possibility and impossibility of understanding others completely, that makes human communication intersubjective and, consequently, intersubjective communication human. As I argued, it is due to Giovanna's ambiguous cross-diegetic gestures that the filmic gaze of Facing Windows oscillates and that at moments such as during Giovanna's hallucination we have a sense as if the film itself was looking at us.

\section{The Hectically Oscillating Gaze of Moonrise Kingdom}

Whether Moonrise Kingdom looks at or through us is difficult to tell, since Wes Anderson's filmic gaze combines all the viewing mechanisms which I have been discussing up to now, and more. By drawing us into omniscient and restricted points of view it passivises us, by "favouring carefully crafted tableaus" it makes us aware of the performance of our watching (Goldberg n. pag.), and by repeatedly addressing us through not one but various characters yet withdrawing the direct gaze the very next moment, it offers a completely baffling spectatorial experience. The sudden shifts between different modes of address underpin the idea that Moonrise Kingdom casts a hectically oscillating gaze upon its viewers. As Lily Goldberg argues, this is a film "in which the 'look' is constantly negotiated." Yet while Goldberg refers to the contested dominance of the male gaze within the diegesis of Moonrise Kingdom, I shall apply the notion of the constantly negotiated look to describe the special dynamics between this film and the audience, because viewers can never have a clear sense of who does the gazing: they or Moonrise Kingdom, the looking subject.

The plot in Moonrise Kingdom revolves around two teenage runaways: Sam, who feels cast out because the other boys in his scout unit believe that as an orphan he is "emotionally disturbed," and his pen pal, Suzy Bishop, who has problems controlling her violent outbursts and is treated as a "very troubled child" by her family.

8 It seems that addressivity is in crisis from the very beginning; the miscommunications within the family, Giovanna talking to thin air about love, the undelivered letter written by Davide to Simone, let alone Giovanna's voyeuristic fantasies about Lorenzo, all demonstrate that it is impossible to express desire without misdirecting it. 


\section{BORBÁLA LÁSZLÓ}

Fed up with being labelled as cantankerous, naughty kids, they escape together like adult lovers. During their journey across the island of New Penzance they find a beach which becomes their haven and which they call Moonrise Kingdom, while their freedom is threatened by the scouts, the police, and the Bishop family, who are all trying to track them down.

As Dana Bubulj argues, the "initial attraction of two children who don't seem to fit in with their peers/siblings and decide to run away together is something the audience watching can key into as nostalgic escapism." This means that while the film is centred around the trope of scopophilia resulting from emotional alienation, estrangement, dysfunctionality, and failure of communication within the family, it also presents a metanarrative of escaping the aforementioned problems as a gesture to restore our romantic, optimistic, intersubjective relation to fiction. Thus, similarly to Facing Windowes, Moonrise Kingdom tackles the issue of addressivity not only within the diegetic world, but also through references to the film's mode of address which is so utterly ambiguous that it evokes the fancy of the film being a capricious teenage child. It is not by chance that the filmic gaze is manifested in the eyes of the main female character Suzy, whose attitude towards the viewers changes abruptly: one moment we are invited to see through her eyes only to be pushed away as intruders the very next moment.

As a window to the world in which viewers never know where they stand, Moonrise Kingdom opens with a scene that both beckons and repels the audience. The camera starts panning the interiors of the Bishop family house that stands on Summer's End, a remote corner of New Penzance. An embroidered picture hanging on the wall depicts the house itself, so that when the camera shows the building from outside, one might wonder whether this is not just another mise-en-abyme in the many-layered representational maze. One stratum in this world is a cluster of references to Rear Window, which makes Moonrise Kingdom an intertext of one of the most influential movies about the gaze, and consequently, a metacinematic manifestation of the voyeuristic mode of watching films.

The opening scene already contains a series of references to the act of watching. As Goldberg explains, "Anderson's tracking shots normalise the violation of the Bishop family's privacy by providing an omniscient and impossible viewpoint, relieving the viewer of the feeling that such voyeurism is realistic while simultaneously inviting the viewer to partake in surveillance." Apart from the voyeuristic panning shots, the opening scene also foregrounds the motifs of windows and binoculars, 
both of which signify the act of looking, and, more precisely, watching films: just like in Rear Window, the curtains are opened as if they were eyelids opening to the external world. However, the flow of intertextual references is arrested when we get a reverse-shot that shows the exterior of the house with Suzy standing in the window and staring directly at us through her beloved binoculars.

This sudden shift between opposing modes of address epitomises the whole fabric of the film insofar as "every time the viewer becomes comfortable accepting Anderson's surveillant practices as a natural aspect of his filmmaking, Suzy appears suddenly, gazing intently back at the viewer" (Goldberg). As Goldberg further argues,

[t]hroughout Moonrise Kingdom, viewers are invited to assume Suzy's gaze through the usage of binocular shots, wherein the ocular circles of Suzy's binoculars frame a wide or panning shot. The addition of the binocular frame lends these shots a constructed intimacy, as the purpose of binoculars is to narrow the gaze on a person of interest. These binocular shots are explicitly voyeuristic; this voyeurism depends upon the viewer's recognition of Suzy as the articulator of the gaze.

Although I agree with Goldberg that the shots framed by Suzy's binoculars are explicitly voyeuristic, I would not go so far as to state that they evoke a sense of intimacy. The intimacy evoked might exist between character and character, but not between character and audience. Instead, recalling my former claim in connection with Rear Window, I would suggest that the framing of the camera is a reference to the spectator's limited agency in relation to the filming device.

In my view, the scenes in Moonrise Kingdom which, by means of reference, insert the ocular circles of the camera into the mise-en-scène serve to distance the audience by reminding them of the impossibility of leaving the absolute point of view provided by the film. However, with a sudden shift from a binocular shot to a reverseshot showing Suzy directly gazing at the audience, Moonrise Kingdom also invites a more active spectatorial agency. One could even assume that Moonrise Kingdom is the reversed image of Rear Window, the camera obscura of the camera obscura, since while Hitchcock's film places both the aperture and the absolute point of view in the same vertical dimension, thereby making them occupy the same optical field, Moonrise Kingdom occasionally positions the viewer on the infamous "other side" which 


\section{BORBÁLA LÁSZLÓ}

is unattainable for Jeffries, and by doing so, it creates the sense of the film watching us through the character's binoculars. The result of this, as Goldberg puts it, is that "the unwavering presence of the camera's look in Anderson's films might prevent viewers from partaking in the voyeuristic identification."

Another element which enhances the oscillations of Wes Anderson's filmic gaze is the use of sound and voice. In the opening scene, we first perceive sound in the form of intra-diegetic music, as the Bishop children begin listening to Benjamin Britten's Young Person's Guide to the Orchestra, but at the same moment when Suzy breaks the fourth wall, the melody enters the extra-diegetic sphere, thus serving as a musical counterpoint to the metalepsis visually performed by the character. As Imani Mosley states, "[t]he play of space blurs the line of how we as viewers are supposed to experience the music, asking the listener to understand what they hear as part of their world as well as of the world on screen." The fact that "much of the music is heard by both the audience and the characters inside the film" makes one suppose that the characters also see what we see, thus the ambivalent use of sound and music also contributes to destabilising the dichotomy between spectacle and spectator, between fiction and reality.

The ambiguous mode of address introduced by the opening scene is characteristic of the whole fabric of the film, and the repeated but ambivalent appearances of direct address play a crucial role in achieving this effect. Regarding the use of this device in Anderson's films, Brown suggests that "the question of whom the characters are looking at when they look at the camera is difficult to discern" (175). This means that at one moment we are certain that the character is looking at us, breaking down the fourth wall, only for an immediate insertion of a reverse shot to revert the extra-diegetic gaze into the diegetic world, restoring the sense of being immersed into fictional reality.

The scene when the two runaways are finally found by the search party illustrates the intensity of the oscillation of the filmic gaze. Hiding in a tent on the beach, aware that their liberty will soon be curtailed again, the kids hug each other protectively while projecting frightened looks into the camera, so that we feel like intruders in their world. Similar to the hallucinatory scene in Facing Windows, this scene makes us uncomfortably conscious of our voyeuristic mode of watching films, to the point that we feel that we are spying on the characters. In such moments, the viewer is identified not with Suzy and Sam's perspective, but with the parents and the scouts, that is, those who encroach upon the shared intimacy of the two 
runaways. However, the camera position abruptly changes once again, and we are shown Suzy's father lifting the kids' tent above his head with all the other members of the search party lined up behind him. Right after being identified and confronted as voyeurs, we are relieved of the burden of conscious watching and of being watched by the characters.

Although in Wes Anderson's film several characters are endowed with an ambiguous awareness, that is, they repeatedly use direct address which they subsequently also withdraw, I regard the character of Suzy the most important in creating an intersubjective connection with the audience, because as a "troubled child," she shares the capriciousness of the filmic gaze of Moonrise Kingdom. In the scene where Suzy and Sam are watching deer through her binoculars, the girl says (about the stag): "He knows someone's watching him. I just think he can feel us." Although not addressing the audience directly, Suzy here instils the feeling in the viewer that she knows that she is part of the fictional world and that we are looking at her. Her intradiegetic comment is a gesture directed towards the audience. However, as she later explains her obsession with peeping, her binoculars "help [her] see things closer, even if they're not very far away," and she consistently refers to them as the source of her "magic power" throughout the film. These remarks on scopophilia highlight not the distancing effect of direct address, which would construct the viewer as voyeur, but its potential of providing clairvoyance, of mentally and emotionally involving the viewer into the lifeworld of the character. More clearly put, although Suzy frequently uses her binoculars to look directly at us, the way she perceives peeping emphasises the desire to see, to know things better, to create connections between people within and beyond the boundaries of the fictional universe rather than aiming at alienation.

In this sense, Suzy is very similar to Giovanna in La Finestra di Fronte, because her eyes, meaningfully mascaraed with bright-blue eye shadow, carry special significance in addressing the viewers and can be perceived as projecting the filmic gaze per se. Yet, since Ozpetek's movie is closer to classical narrative cinema, Giovanna occupies a superior sensorial but not a superior epistemic position: although she is more sensitive to the spectator's presence than other characters, she does not address us directly, she does not seem to know that we are watching her character. Giovanna's superior position is never separated from her intra-diegetic characterposition and Facing Windows does not perform such sudden, chiasmic shifts between intra and extra-diegetic roles as Moonrise Kingdom. In the latter movie, on the other 


\section{BORBÁLA LÁSZLÓ}

hand, even though Suzy's extra-diegetic gazes are instantly withdrawn and are integrated into the coherent fabric of the film, she seems to be in a "a position of greater knowledge within the fiction than other characters" (Brown 14). As Rachel Joseph claims, the consistent "acknowledgement of the camera and an audience watching the spectacle unfold brings forth a kind of "cinema of attractions" in the case of Moonrise Kingdom, "that makes the whole film framed by an intentional theatricality and address to the audience" (60).

Similar to Giovanna, Suzy's character also functions as the film's narrator. According to Irini Kalesi's insightful observation, the narrative fabric of Moonrise Kingdom is comprised of three layers, which I believe also entail three distinct modes of address. As Kalesi elucidates,

The first level of narration is carried out by a non-perceptible external narrator who visually presents the story to the audience. The second level is the red-coated narrator who provides the viewers with the background story, foreshadowing aspects and his own judgements ... In the third narrative level, Suzie recites her stories to Sam. (27)

From this narrative structure it follows that, by way of visually immersing the audience into the representational world, the non-perceptible external narrator addresses us as voyeurs, the red-coated narrator verbally addresses us as still quite passive listeners, and, by consistently but ambiguously addressing us through her voice and gaze, Suzy manifests the oscillating mode of address of the whole film.

Suzy's narrator position is also reinforced by her love of reading and reciting fictional stories. As Kalesi argues, she "functions as a storyteller for Sam and thus tries to insert him into her fantasy world" (26). Moreover, the flashback scenes which retell the story of Suzy and Sam's relationship through letters serve as yet another form of intimate address which is most typical of Suzy among all the characters and narrators. ${ }^{9}$ Surrounded by emotionally dysfunctional adults, Suzy uses the personal tone of letters and the voice of fictional narration to suspend her disbelief in the effectiveness of human interactions and to gain - even if imaginary - understanding, empathy, and intimacy. In short, Suzy strongly believes that she can tran-

9 This idea explains why Sam, who actually initiates their correspondence, begins his first letter to the girl with a compliment: "Dear Suzy, you have a superb voice." 
scend the bleakness of her lifeworld, so her quirks - her fits of temper, her obsession with reading and correspondence, and her arguably premature relationship with Sam - are symptomatic of her superior epistemic position which surfaces in moments when she seems to be reading her story directly to us or when she seems to be looking out of her world into ours. All in all, it is due to Suzy's ambiguous address towards viewers that, despite the overwhelming trope of emotional estrangement, the film has "a rapt quality, as if we are viewing the events through Suzy's binoculars or reading the story under the covers by a flashlight" (Jones).

In conclusion, what the analysis of Moonrise Kingdom has shown is that the mode of its address oscillates with great intensity between treating the viewers as passive observers, sympathetic scopophiliacs, unwanted intruders, and equal partners in an intersubjective relationship between film and audience. Compared to Rear Window, A Short Film about Love and Facing Windows, Wes Anderson's film provides the highest amplitude of the changes of the filmic gaze, since it constantly poses the question whether it can split up the suture that is meant to sew the viewer into the unreflective experience of watching films, or, in other words, whether it can break into the dark room of our visual perception. Similarly but more emphatically than Facing Windows, Moonrise Kingdom undermines the binary distinctions between "the cinema of attractions" and "narrative cinema" as well between "gaze cinema" and "glance cinema," since as its characters first look out at us, then retreat into the diegetic world, it shows that the mode of address can change hectically even within an individual cinematic production.

\section{Conclusion}

In this paper the notion of the filmic gaze was not understood as the source of mastery the viewing subject asserts over the cinematic image, that is, as it was introduced by early Lacanian film theoreticians - Baudry, Metz, and Mulvey. Instead, the present notion of the cinematic gaze - evoking the original Lacanian concept - refers to the mode of address, the whole fabric of the film, which is consequently construed as a looking subject. Silverman's suture theory and Descartes's dark room parable were employed to demonstrate this reconceptualised notion of the filmic gaze, and to reveal that most films - even highly self-reflexive ones aiming to call attention to the act of watching - look through rather than at spectators, since their diegesis adheres to maintaining the image-beholder dichotomy. 


\section{BORBÁLA LÁSZLÓ}

Yet, my hypothesis was that there are films which deviate from this convention. By blurring the boundary between an intra-diegetic and extra-diegetic visual experience, these movies look at us mainly through the characters' telltale eyes which occasionally suggests that the film is aware of being watched and is capable of watching us. I argued that such films have a hybrid, oscillating gaze, and since they partly look through us as if we were voyeurs, partly look at us as if we were equal partners in the act of looking, their mode of address can be perceived as a form of intersubjective communication.

Although Tom Gunning and Timothy Corrigan relied on distinct modes of address when they chronologised and categorised trends of film reception, their genealogies fail to account for the oscillating filmic gaze. Consequently, I contend that films which haphazardly address us through the characters' telltale eyes do not fit into the theoretical categories provided by Gunning and Corrigan. I attempted to demonstrate this idea through the comparative analysis of three films, where the fourth, Rear Window, served to prepare the ground for the upcoming argument for the relevance of the term "oscillating filmic gaze."

\section{I selected Krzysztof Kieślowski's A Short Film about Love, Ferzan Ozpetek's Facing} Windores, and Wes Anderson's Moonrise Kingdom, firstly because these movies abound in optical devices representing human eyes, thereby supposedly activating moments of de-suturing, and secondly because the centred themes of peeping, voyeurism, and scopophilia seemed useful to explore the nature of the filmic gaze. In fact, it was necessary to investigate such films, since I was interested in whether their references to the acts of watching and looking inevitably entail a more varied and active spectatorial agency than the one prescribed by conventional film-audience dynamics, or not. In other words, I wanted to examine whether films address the audience depending on or irrespective of existing theoretical classifications.

Through the analyses I found that although the trope of love makes A Short Film about Love a more nuanced rendering of voyeurism than Rear Window, it only enhances the sense of being confined to a limited perspective. Even though the object and subject of the gaze change roles within the diegesis, the audience-pleasing ending and the pervasive presence of circular glass surfaces uphold the conventional filmaudience relation. Thus, despite its references to the illusory mastery of the viewing subject, the first example showed that self-reflexive films do not necessarily grant us active spectatorial agency. Ozpetek's Facing Windowes seemingly complies with the traditions of narrative cinema in as much as it does not break the fourth 
wall until the very end. However, the telltale eyes of Giovanna - who occasionally and ambiguously addresses the viewer - can be perceived as the manifestation of the film's gaze per se, which thereby treats us as both passive observers and as looking subjects. Therefore, Ozpetek's drama demonstrated that movies classified as narrative cinema can also gaze at us and provide active spectatorial agency. The other example that illustrated the oscillatory nature of visual address was Wes Anderson's Moonrise Kingdom, since it hectically varies between treating the viewers as voyeurs and as looking subjects. Similar to Facing Windows, Anderson's movie cannot be classified into either "glance" or "gaze cinema," either "cinema of attractions" or "narrative cinema"; therefore, it also implies that not all films fit into customary theoretical categorisations. Along these lines, my last two examples served to prove that films address the audience irrespective of conventional theoretical categorisations, that in fact, each film regards the viewer in their own special way.

\section{Works Gited}

A Short Film about Love. Dir. Krzysztof Kieślowski. Film Polski, 1988.

Baudry, Jean-Louis. "Ideological Effects of the Basic Cinematographic Apparatus." In Movies and Methods. Ed. Nichols, Bill. Vol. 2. Berkeley, Los Angeles: University of California Press, 1985. 531-543.

Berardinelli, James. "Short Film about Love." Reelviews. n.d. Web. 3 Oct 2019. <http://www.reelviews.net/reelviews/short-film-about-love-a>

Bozovic, Miran. "The Man Behind His Own Retina.” In Everything You Always Wanted to Know about Lacan (But Were Afraid to Ask Hitchcock). Ed. Zizek, Slavoj. London, New York: Verso, 1992. 161-177.

Brown, Tom. Breaking the Fourth Wall: Direct Address in the Cinema. Edinburgh: Edinburgh University Press, 2012.

Bubulj, Dana. "Moonrise Kingdom and Voyeurism (some thoughts)." Dana Bubulj: Sculpture, Film, Shadows, Art. 2012. Web. 20 Oct 2019. <https://danabubulj.wordpress.com/2012/10/10/moonrise-kingdom-voyeurism> Corrigan, Timothy. A Cinema Without Walls: Movies and Culture After Vietnam. New Brunswick, New Jersey: Rutgers Universiry Press, 1991.

Dolar, Mladen. "A Father Who Is Not Quite Dead." In Everything You Always Wanted to Know about Lacan (But Were Afraid to Ask Hitchcock). Ed. Zizek, Slavoj. London, New York: Verso, 1992. 143-150. 


\section{BORBÁLA LÁSZLÓ}

Ellis, John. Visible Fictions: Cinema, Television, Video. London: Routledge, 1982.

Facing Windowes. Dir. Ferzan Ozpetek. Sony Pictures Classics, 2003.

Goldberg, Lily. "Suzy's Stare: A Close Visual Reading of the Female Gaze in Wes Anderson's 'Moonrise Kingdom”" 2018. Web. 21 Oct 2019. <https://lilyngoldberg.com/2018/12/10/suzys-stare-a-close-visual-reading-of-the-female-gazein-wes-andersons-moonrise-kingdom>

Gunning, Tom. "An Aesthetic of Astonishment: Early Film and the (In)credulous Spectator." In Film Theory and Criticism: Introductory Readings. Eds. Braudy, Leo, and Marshall Cohen. Oxford: Oxford University Press, 1999. 818-832.

- D. W. Griffith and the Origins of American Narrative Film: The Early Years at Biograph, Urbana: University of Illinois Press, 1991.

Haltof, Marek. The Cinema of Krzysztof Kieślowski: Variations on Destiny and Chance. London, New York: Wallflower Press, 2004.

Hayward, Susan. Cinema Studies: The Key Concepts. London, New York: Routledge, 2000. Jones, Kristin M. “Review: Moonrise Kingdom.” Film Comment. 2012. Web. 5 Sept 2019. $<$ https://www.filmcomment.com/article/review-moonrise-kingdom>

Joseph, Rachel. "Max Fischer Presents: Wes Anderson and the Theatricality of Mourning." In The Films of Wes Anderson: Critical Essays on an Indiewood Icon. Ed. Kunze, Peter C. New York: Palgrave Macmillan, 2014. 54-62.

Kalesi, Irini. The Andersonian Theatricality. July 2015. University Amsterdam, Master's Thesis.

"Key Aspects of Media Studies." n.p., n.d. Web. 21 Sept 2019. <https://cpb-eu-w2. wpmucdn.com/edublog.mgfl.net/dist/a/14/files/2016/10/KEY-ASPECTSOF-MEDIA-STUDIES-1c9n8hf.pdf>

Lacan, Jacques. The Four Fundamental Concepts of Psychoanalysis. Trans. Alan Sheridan. New York: Norton, 1998.

Mayne, Judith. Cinema and Spectatorship. London, New York: Routledge, 1993.

McGowan, Todd. "Looking for the Gaze: Lacanian Film Theory and Its Vicissitudes." Cinema Fournal 42.3 (2003): 27-47.

-. The Real Gaze: Film Theory after Lacan. Albany: State University of New York Press, 2007.

Metz, Christian. The Imaginary Signifier: Psychoanalysis and Cinema. Trans. Celia Britton, et. al. Bloomington: Indiana University Press, 1982.

Moonrise Kingdom. Dir. Wes Anderson. Focus Features, 2012. 


\section{STORIES OF TELLTALE EYES}

Mosley, Imani. "This Is Music of a Special and Singular Power: Britten andDiegetic/Nondiegetic Music in Wes Anderson's Moonrise Kingdom.” Apr 2015. Web. 15 Oct 2019. <https://www.academia.edu/6768752/_This_is_music_of_a_special_and_singular_power_Britten_and_Diegetic_Nondiegetic_Music_in_Wes_Anderson_s_ Moonrise_Kingdom>

Mulvey, Laura. "Visual Pleasure and Narrative Cinema." In The Sexual Subject: A Screen Reader in Sexuality. Eds. Caughie, John, and Annette Kuhn. London: Routledge, 1992. 22-34.

Occhipinti, Emauele. New Approaches to Teaching Italian Language and Culture: Case Studies from an International Perspective. Cambridge Scholars Publishing, 2008.

Oudart, Jean-Pierre. “Cinema and Suture.” Screen 18.4 (1977): 35-47.

Rear Window. Dir. Alfred Hitchcock. Paramount Pictures, 1954.

Reeve, C. D. C. "Lessons in Looking: Krzysztof Kieślowski's A Short Film about Love." In Understanding Love: Philosophy, Film, and Fiction. Eds. Wolf, Susan, and Christopher Grau. Oxford: Oxford University Press, 2014. 271-285.

Rowe, Allan. "Film form and narrative." In An Introduction to Film Studies. Ed. Nelmes, Jill. London, New York: Routledge, 1996. 87-120.

Silverman, Kaja. The Subject of Semiotics. New York: Oxford University Press, 1983. Staiger, Janet. Perverse Spectators: The Practices of Film Reception. New York, London:

New York University Press, 2000.

Stok, Danusia (ed.). Kieslowski on Kieslowski. London: Faber and Faber, 1993.

Zizek, Slavoj. "Alfred Hitchcock, or, The Form and its Historical Mediation." In Everything You Always Wanted to Know about Lacan (But Were Afraid to Ask Hitchcock). Ed. Zizek, Slavoj. London, New York: Verso, 1992. 1-12.

\section{Contributor Details}

Borbála László, PhD student at the Doctoral School of Literary and Cultural Studies at the University of Debrecen, is engaged in animal studies, exploring the (inter)relations between human and nonhuman animals in cultural products, with a particular interest in the biopolitical and bioethical implications of representing dogs in literature, popular and art films. Her academic interests extend to film and phenomenology as well as to the theoretical issues surrounding the cinematic gaze. 